\title{
Günübirlik Cerrahi Sonrası Ağrı Yönetiminde Hemşirelik Yaklaşımı
}

\author{
Nursing Approach in Pain Management After Daily Surgery \\ İbrahim KIYA T $^{\mathbf{1}}$ A,B,D,E,F,G ${ }_{\mathbb{C}}$ \\ ${ }^{1}$ Kırklareli Üniversitesi, Hemşirelik Bölümü, Kırklareli, Türkiye
}

\begin{abstract}
ÖZ
Ayaktan cerrahi olarak da bilenen günübirlik cerrahinin kullanımı her geçen gün artmaktadır. Günübirlik cerrahi sonrası bazı istenmeyen durumlar arasında ağrı yer almaktadır. Multidisipliner ekip anlayışı ile yönetilmesi gereken ameliyat sonrası ağrı, hastaların günlük bakımından sorumlu olmalarından dolayı hemşireleri merkezi bir konuma getirmektedir. Günübirlik cerrahi sonrası ağrı yönetimi, ameliyat öncesi bilgi ve eğitim vermeyle başlamaktadır. Ameliyat öncesi eğitim, hastanın durumuna ve yapılan cerrahiye göre planlanmalıdır. Ağrı değerlendirmesi, yapılan uygulamaların etkinliklerini değerlendirmek için periyodik olarak yapılmalıdır. Bunun için uygun ağrı değerlendirme ölçeklerinin tercih edilmesi gerekmektedir. Ameliyat öncesi yaşanan anksiyete ile ameliyat sonrası ağrı arasında doğru bir orantı vardır. Hemşireler, hastaların var olan endişelerini paylaşması için cesaretlendirmeli ve soru sormalarına olanak sağlamalıdır. Klinik uygulama kılavuzları, ameliyat sonrası ağrı yönetiminde multimodal analjezinin kullanılmasını önermektedir. Multimodal analjezinin yanı sıra preemptif analjezi, günübirlik cerrahide ameliyat sonrası ağrıyı kontrol etmek için kullanılan stratejidir. Bu stratejiler hasta sonuçlarını iyileştirebilir. Hemşireler, hasta güvenliğini göz önünde bulundurarak hem farmakolojik hem de farmakolojik olmayan yöntemleri içeren multimodal bir yaklaşımı tercih etmelidir. Başarılı bir taburculuk ameliyattan önce başlamalıdır. Taburculuk planı içerisinde hastanın evde ağrı kontrolünü nasıl yönetebileceğinden bahsedilmelidir. Hasta ile telefon görüşmesi yaparak taburculuk sonrası izlem ve takip devam ettirilmelidir. Taburculuk sonrası izlemin hasta memnuniyetini artırma potansiyelinin yanında evde genel olarak yaşanan sorunların neler olduğu da öğrenilebilir. Taburculuk sonrası izlem, hasta memnuniyetini artırma potansiyelinin yanında, evde genel olarak ne tür sorunların yaşandığını da gösterebilir. Bu sorunlarla ilgili hemşire ve günübirlik cerrahi ekibi protokoller oluşturabilir. Protokoller standart uygulamaları meydana getirerek günübirlik cerrahi sonrası ağrı yönetiminde yol gösterici olabilir.
\end{abstract}

Anahtar Kelimeler: Ağr1 yönetimi, ayaktan cerrahi, günlük cerrahi, perioperatif hemşirelik, postoperatif ağrı.

\section{ABSTRACT}

The use of day surgery, which is also known as outpatient surgery, is increasing day by day. Pain is among some undesirable conditions after day surgery. Postoperative pain, which must be managed with a multidisciplinary team approach, places nurses in a central position because they are responsible for the daily care of patients. Post-day surgery pain management begins with preoperative information and training. Preoperative training should be planned according to the patient's condition and the surgery performed. Pain assessment should be done periodically to evaluate the effectiveness of the applications. For this, appropriate pain assessment scales should be preferred. There is a correct proportion between anxiety experienced before surgery and postoperative pain. Nurses should encourage patients to share their concerns and allow them to ask questions. Clinical practice guidelines recommend the use of multimodal analgesia in postoperative pain management. In addition to multimodal analgesia, preemptive analgesia is the strategy used to control postoperative pain in day surgery. These strategies can improve patient outcomes. Nurses should prefer a multimodal approach that includes both pharmacological and nonpharmacological methods, taking patient safety into consideration. A successful discharge should begin before surgery. In the discharge plan, it should be mentioned how the patient can manage pain control at home. Monitoring and follow-up should de continued after discharge by making a phone call with the patient. In addition to the potential of post-discharge follow-up to increase patient satisfaction, the problems experienced at home in general can be learned. Post-discharge follow-up, besides its potential to increase patient satisfaction, can also show what kind of problems are experienced at home in general. The nurse and day surgery team can create protocols for these problems. Protocols can be a guide in pain management after day surgery by establishing standard practices.

Sorumlu Yazar: İbrahim KIYAT

Kırklareli Üniversitesi, Hemşirelik Bölümü, Kırklareli, Türkiye

ibrahimkiyat@klu.edu.tr

Geliş Tarihi: 17.05.2020 - Kabul Tarihi: 06.12.2020

Yazar Katkıları: A) Fikir/Kavram, B) Tasarım, C) Veri Toplama ve/veya İșleme, D) Analiz ve/veya Yorum, E) Literatür

Taraması, F) Makale Yazımı, G) Eleştirel İnceleme 
Key Words: Day surgery, outpatient surgery, pain management, perioperative nursing, postoperative pain.

\section{GİRIŞ}

Günübirlik cerrahi, dünya genelinde gün geçtikçe artış göstermektedir ve bu artışın devam edeceği ön görülmektedir. Ayaktan cerrahi olarak adlandırılan günübirlik cerrahi, ilk kez 1909'da yapılmış olmasına rağmen, son yirmi yıl içinde güçlü bir şekilde gelişmiştir (1-4). Günümüzde elektif cerrahilerin çoğu günübirlik olarak yapılmaktadır. Erken taburculuk, hızlı bir iyileşme, sağlık bakım maliyetinde azalma, cerrahi ve anesteziye bağlı yan etkilerin düşük insidansı, günübirlik cerrahiyi avantajlı kılmaktadır. Günübirlik cerrahide, hasta sağlık kuruluşuna gelir, ameliyatı yapılır ve aynı gün taburcu edilip eve gönderilir (1,5-8).

Günübirlik cerrahinin tercih edilmesinde; teknolojideki ve nitelikli bakım alanındaki hızlı ilerlemeler, ekonomik faktörler, hastaların tercihleri, geliştirilmiş analjezi ve anestezi yöntemleri, cerrahi tekniklerdeki gelişmeler, yandaş hastalıkları olan hastalara daha kapsamlı cerrahi yöntemler sunulması, minimal invaziv cerrahi yöntemlerin kullanılabilirliğinin artması gibi durumlar etkili olmaktadır $(3,6)$.

Günübirlik cerrahi sonrası, ağrı, enfeksiyon, yorgunluk, bulantı, kusma, uykusuzluk vb. gibi istenmeyen durumlar ortaya çıkmaktadır. Ameliyat sonrası ağrı, bu istenmeyen durumların en belirgin örneğini teşkil etmektedir (9). Hastaların taburcu olduktan sonra beklenmedik hastane başvuru nedenleri arasında ameliyat sonrası ağrı, önde gelmektedir. Sağlık bakım maliyetlerinde artmaya, kronik ağrıya, hastaların yaşam kalitesinde bozulmaya, morbidite ve mortaliteye neden olduğu için hastalar ve cerrahi ekip açısından büyük bir endişe kaynağıdır (10-12).

Günübirlik cerrahide, etkili ağrı yönetimi zor bir konudur. Kontrolsüz ağrı, sadece fiziksel sıkıntıya neden olmaz; aynı zamanda uzun süreli hastanede kalış ve hastaneye yeniden yatış ile sonuçlanabilir. Bunun bir sonucu olarak iyileşmenin gecikmesine, ameliyat sonrası komplikasyonlara ve işe geç başlamalara neden olabilir (13-15). Tanımlayıcı ve kesitsel nitelikteki bir çalışmada, taburculuk sonrası ilk 24 saatte hastaların \%73.6'nı ağrı yaşadığı tespit edilmiştir (16). Benzer şekilde Aydoğdu ve Yılmaz (2020), yapmış oldukları çalışmada, günübirlik cerrahi sonrası taburcu olan hastaların, ilk 24 saat içerisinde, \%75'inin; 2-7 gün içinde ise \%35.6'sının ağrı yaşadığını belirtmiştir (17). Günübirlik cerrahi sonrası orta ile şiddetli ağrı insidansı \%15-70 arasında değişmektedir. Ağrı şiddeti yapılan cerrahi ameliyata bağlı olarak değişir. Şiddetli ağriya neden olan prosedürler arasında lomber mikrodiskektomi, laparoskopik kolesistektomi, inguinal herni, omuz, dirsek/el, ayak bileği ve diz cerrahileri yer almaktadır (10.15).

Yüksek anksiyete, kronik ağrı ve opioid toleransına sahip hastalar, günübirlik cerrahi sonrası ağrı yaşama riski yüksek kişilerdir. Ağrı yaşama riski yüksek hastaları belirlemek için ameliyat öncesinde ağr değerlendirmesinin yapılması gerekmektedir (11). Bu değerlendirme, multidisipliner ekip anlayışı çerçevesinde yürütülmelidir. Günübirlik cerrahide multidisipliner ekip; sorumlu hekim, cerrah, anestezist, hemşire, fizyoterapist gibi üyelerden oluşmaktadır. Ekibin içine sadece sağlık uzmanları değil; hasta ve hasta yakınları da dahil edilmelidir (6). Bu ekipte hasta bakımının merkezinde yer alan hemşireler, cerrahi sonrası ağrı yönetimine liderlik etmektedir. 


\section{Günübirlik Cerrahi Sonrası Ağrı Yönetiminde Hemşirelerin İzleyebileceği Bazı Stratejiler}

Ağrının başarılı yönetimi, gerçekçi beklentiler ve ameliyat öncesi eğitim ile başlamaktadır. Ameliyat öncesi ağrı yönetiminin gerekliliğini anlamak, ağrı değerlendirmesi yapmak, psikolojik destek sağlamak, uygun anestezi sonrası bakım ünitesinde (ASBÜ) ağrı yönetimini optimize etmek, preemptif ve multimodal analjezi uygulamalarını kullanmak, ameliyat sonrası etkili taburculuk planı yapmak ve taburculuk sonrası takip ve değerlendirmeyi iyi yönetmek günübirlik cerrahi hastasında optimal ağrı yönetimini kolaylaştıracaktır $(18,19)$.

\section{Ameliyat öncesi eğitim:}

Ağrı, ameliyatın kaçınılmaz bir sonucudur. Ameliyat sonrası etkili ağrı yönetimi, ameliyat öncesi başlar. Bu yüzden, ameliyat sonrası ağrıyı önlemek için mümkün olduğunca erkenden ağrı yönetimine başlanmalıdır. Hemşirelerin profesyonel rollerinden olan eğitim ve danışmanlık rolü bu süreçte daha da önem kazanmaktadır. Çalışmalar, ağrı kontrolü ile ilgili ameliyat öncesi yapılan eğitimin hastaların analjezik kullanımını ve endişesini önemli derecede azalttığını ortaya koymaktadır. Eğitim ve danışmanlık, analjezik uygulama stratejilerine karşı olan uyumu geliştirmektedir $(9,19)$.

Ağrı şiddeti, hastanın yaşına, fiziki durumuna ve cerrahinin doğasına bağlı olarak önemli ölçüde farklılık göstermektedir. Hastanın ameliyat sonrası döneme hazırlanabilmesi için ağrının farklı ameliyatlara göre değişeceğini bilmesi önemlidir. Bunun için ameliyattan önce, hasta değerlendirme sırasında ameliyata özgü broşürler veya ameliyata bağl1 gelişebilecek ağrının yönetimi hakkında bilgi verebilecek videolar kullanılabilir. Hasta ile birlikte ağrı yönetim stratejileri belirlenmeli ve ameliyat sonrası iyileşmenin optimize edilmesi için atılabilecek adımların neler olduğu gözden geçirilmelidir. Hasta ve yakınları cerrahi süreçte hemşire ve diğer sağlik ekibinin bilgilendirmelerini unutabileceğinden, önemli bilgilerin tekrarlanması, yazılı ve görsel içerikli materyaller verilmesi gerekmektedir $(10,20)$.

\section{Ağrı tanılaması/değerlendirmesi:}

Ameliyat sonrası ağrıyı etkili bir şekilde yönetmek için önce ağrının değerlendirilmesi gerekir. İhtiyaç duyulan analjezik ilacın derecesini ve uygulanan tedavinin etkinliğini belirlemek için uygulama öncesi/sonrası ağrı yeniden değerlendirilmelidir. İyileşmeyen ağrının genel sebepleri arasında ağrının yeterince tanımlanmaması ve giderilmemesi yer almaktadır $(19,21)$.

Subjektif bir kavram olan ameliyat sonrası ağrının, doku hasarına bağlı olarak tahmin edilmesi mümkün değildir. Bu nedenle sadece ağrıyı yaşayan hasta tarafından en doğru şekilde tanımlanabilir. Ameliyattan önce hastanın yaşına, bilinç durumuna uygun olarak kullanılacak ağrı değerlendirme ölçeklerinden bahsedilmelidir. Hastalar ölçeğin amacının ne olduğunu, nasıl kullanıldığını görmeli ve anlamalıdır. Ameliyat sonrası ağrının şiddetini ve niteliğini değerlendirmek için uygulanması basit, anlaşılması kolay, maliyeti düşük, geçerlilik ve güvenirliliği kanıtlanmış ölçekler tercih edilmelidir $(19,21)$.

Ameliyat sonrası ağrı değerlendirmesinde; 0'dan 10'a kadar ağrı şiddet derecesini gösteren 0 ağrı yok 10 ise dayanılmaz ağrı var anlamına gelen sayısal ölçek; "ağrı yok, hafif ağrı, orta ağrı, şiddetli ağrı ve çok şiddetli ağrı” şeklinde tanımlanan sözel kategori ölçeği; yaşlı, 
pediatrik ve sayısal ölçeği kullanamayan popülasyon için geliştirilen ve gülümseyen, ağlayan vb. gibi yüz ifadeleriyle ağrı şiddetinin temsil edildiği ölçekler en sık kullanılan ölçeklerdendir $(19,21)$.

Yaşlı popülasyonda ağrı değerlendirmesi genellikle göz ardı edilmektedir. Yaşlılarda ağrı algısı ve eşiğinin azaldığı tutumu kabul edilmemelidir. Yaşlı insanların inanışlarından dolayı ağrı bildirmekten kaçındığı göz önüne alınmalıdır. Ayrıca yetişkinler için geliştirilen değerlendirme ölçeğini yaşlı hastalar kullanmakta zorlanabilir. Bu özel popülasyonda var olan ağrıyı ortaya çıkarmak için teşebbüslerde bulunulmalı, ağrı sık olarak değerlendirilmeli ve yaşlı hastanın sözlü/sözsüz ağrı ifadeleri dikkate alınmalıdır $(11,22)$

Ameliyat sonrası ağrının yönetiminde sadece ağrı tanılaması/değerlendirmesi yapmak tek başına yeterli olmamaktadır. Ağrı tanılaması/değerlendirmesine ek olarak psikolojik destek sağlamak, anestezi sonrası bakım ünitesinde (ASBÜ) ağrı yönetimini devam ettirmek, preemptif ve multimodal analjezi, non-farmakolojik tedavileri kullanmak günübirlik cerrahi sonrası iyileşmeyi kolaylaştıracaktır (19).

\section{Ameliyat öncesi ve sonrası psikolojik destek:}

Anksiyetenin ağrı algısı ve yönetimi üzerinde olumsuz bir etkisi olduğu iyi bilinmektedir. Ameliyat yapılması planlanan hastaların genellikle hastaneye yatışı yapılacak olmasından ve ameliyattan dolayı anksiyetesi çok yüksektir (3). Bu durum ameliyat sonrası ağrıyı şiddetlendirebilir. Ameliyat sonrası ağrı şiddetini ve diğer komplikasyonları azaltmak için hastanın psikolojik durumu değerlendirilmelidir. Her hastanın bakımında terapötik bir yaklaşım sergilenmeli ve kendi bireysel özellikleri dikkate alınmalıdır $(8,12)$.

Hemşireler, ağrının çok boyutlu bir deneyim olduğunu ve sadece ağrı şiddetini gösteren sayısal bir skor olmadığını unutmamalıdır. Hastanın kaygısının giderilmesinde yol gösterici olmalıdırlar. Buna bağlı olarak, hastada kaygı uyandıran durumları tespit etmeli ve hastayı kaygılarını paylaşması konusunda cesaretlendirmelidirler. Olumlu tutumlar geliştirerek günübirlik cerrahi süreci boyunca hasta ve yakınlarına bilgilendirmede bulunmalılar, var olan sorularına uygun cevaplar vermeliler, gerekirse günübirlik cerrahi ekibinden yardım istemelidirler $(8,12)$.

\section{Anestezi sonrası bakım ünitesinde (ASBÜ) ağrı yönetimi:}

Günübirlik cerrahiden hemen sonra ASBÜ'ye alınan hastalar, ameliyat sıras1 dönemdeki analjezik ve anestezik ilaçların etkisi ile ağrı yaşamazlar. Fakat hastalar ASBÜ'den taburcu edildikten sonra ağrı yönetimi bozulur. Ameliyat sonrası ağrı, genellikle ameliyat sırası dönemde uygulanan analjezik ve anestezik ilaçların etki süresinden daha uzundur. Bu sorundan kaçınmak için hemşireler analjezik ajanın farmakolojisini iyi bilmeli ve ajanların etki süresi bitmeden önce ameliyat sırası analjezik ilaçları uygulamalıdır (20).

\section{Preemptif (önleyici) ve multimodal (dengeli) analjezi:}

Ameliyat sürecinde hemşireler, preemptif ve multimodal analjezinin mantığını iyi kavramalıdır. Preemptif analjezi, henüz ağrı oluşmadan önce ameliyat sonrası ağrıyı azaltmak için analjezik ilaçların kullanılmaya başlanmasıdır. Henüz yeni bir kavram olan preemptif analjezi operasyon sonrası ağrı yoğunluğunda azalmaya yol açmaktadır. Preemptif analjezi tedavisine sadece preoperatif dönemde uygulanmamalı, ameliyat sırası ve ameliyat sonrası 
dönemde de devam ettirilmelidir. Multimodal yaklaşım günübirlik cerrahide 1990'lı yılların ortalarında uygulanmaya başlanmıştır. Ağrı yönetiminde preemtif ve multimodal yaklaşım, günübirlik cerrahi sonrası ağrının önlenmesinde hızlı bir şekilde altın standart haline gelmiştir. Amerikan Ağrı Derneği ve Amerikan Anestezistler Derneği ameliyat sonrası ağrı tedavisinde multimodal yaklaşımın kullanılmasını tavsiye etmektedir. (18,22-26). Multimodal analjezi, analjezik etkinliği maksimum düzeye çıkarmak ve yan etkileri minimuma indirmek için farklı etkiye sahip analjezik ilaçların yaratmış oldukları sinerjik etkiden yararlanarak kombine olarak kullanılmasıdır $(27,28)$. Opioid (narkotik), nonopioid analjezik (narkotik olmayan analjezik) ve adjuvan ilaçlar, birlikte kullanılmasının sakıncalı olmadığı durumlarda, rutin olarak dengeli analjezik stratejisinin bileşenleri olarak uygulanabilir. Ameliyat sonrası ağrı yönetiminde dengeli yaklaşımda farmakolojik tedavilerin yanında non-farmakolojik tedaviler de yer almaktadır (28).

\subsection{Farmakolojik yöntemler}

\subsubsection{Narkotik (opioid) analjezikler:}

Akut ağrının tedavisinde önemli bir role sahip olan opioidler, uzun yıllardır ağrı yönetimi için kullanılmaktadır. Hidromorfon hidroklorür, morfin ve meperidin orta ila şiddetli ağrıyı tedavi etmek için kullanılan kuvvetli opioid analjeziklerdir. Kodein, proksifen (doloksen) ise daha az yoğunluktaki ağrıyı kesmek için kullanılan zayıf opioid analjeziklerdir. Ağrı yönetiminde etkili rolü olan narkotik analjezik ilaçlar intravenöz, deri altı, intramüsküler, transdermal, peroral gibi çeşitli yollardan uygulanabilmektedir $(18,21)$.

Hidromorfon hidroklorür ameliyat sonrası ağrının akut tedavisinde yaygın olarak kullanılmaktadır. Diğer opioid ilaçlarda olduğu gibi hidromorfonun dozu arttıkça hastalarda solunum depresyonu, sedasyon, konstipasyon, bulantı ve kusma gibi yan etkiler oluşmaktadır. $\mathrm{Bu}$ etkiler, nalokson gibi hızlı etki gösteren opioid antagonistleri tarafından tedavi edilebilir. Nalokson, oral yoldan alındığında emilimi yavaş olduğu için parenteral yoldan uygulanmalıdır. Nalokson, etki süresi çoğu narkotik ilaçtan daha kısa olduğu için tekrar dozuna gereksinim duyulmaktadır. Nalokson'u aşırı dozda veya hızlı uygulamak taşikardi, pulmoner ödem, epileptik krizler, inme gibi istenmeyen etkileri ortaya çıkarabilir. Bu yüzden, ameliyat sonrası küçük dozlar halinde uygulanmalıdır $(18,19)$.

Cerrahi hemşireleri, narkotik analjezik ilaçların ve antagonistlerinin etki mekanizmasını iyi anlamalı ve yan etkilerine karşı dikkatli olmalıdır. Günübirlik cerrahi sonrası büyük miktarlarda opioid ilaçlar kullanmak hastanın geç taburcu olmasına neden olabilir. Opioid ilaçları kontrendikasyonu olmadığı sürece diğer analjezik ilaçlarla kombine şekilde kullanmak hastanın erken dönemde taburcu olmasını sağlamaktadır $(18,19)$.

\subsubsection{Nonopioid analjezikler:}

Dünya Sağlık Örgütü (DSÖ)'nün analjezik merdiveninin ilk basamağında parasetamol, nonstreoid antiinflamatuar ilaçlar (NSAİi) yer almaktadır. Nonopioid analjezikler hafif ağrılarda tek başına etkiliyken orta şiddetteki ağrının tedavisinde opioid analjezikler ile kombine kullanılmalıdır $(18,29)$.

Parasetamol ilaçlar hem analjezik hem de antipiretik etkiye sahiptir. Bu gruptaki ilaçlar NSAIII'lere nispeten yan etkileri daha azdir. Genellikle preemptif olarak ameliyat öncesi ve ameliyat sırasında intravenöz infüzyon şeklinde uygulanan parasetamol ilaçlar ameliyat sonrası 
ağrıyı azaltmaktadır. Niteliksel araştırmalar, asetaminofenin multimodal ağrı yönetiminin bir stratejisi olarak kullanıldığında, ameliyat sonrası ağrının daha az yaşandığını ve opioide olan bağımlılı̆̆ın azaldığını göstermiştir (18,19,29).

Nonstreoid antiinflamatuar ilaçlar antipiretik, antienflamatuar ve analjezik etkiye sahiptir. En önemli yan etkileri, gastrointestinal ülserasyon, kanama, perforasyon ve renal toksisitedir. Hastanın ameliyat sonrası dönemde NSAIII'ler ile birlikte kraker yemesi ve bir bardak su ile içmesi gatrointestinal sistem üzerindeki yan etkilerini azaltmaktadır. Ketorolak preemptif olarak uygulandığı zaman ameliyat sonrası ağrıyı azaltan NSAİ grubu bir ilaçtır. Dengeli analjezinin bir parçası olarak opioidlerle birlikte kullanıldığında etki güçleri artmaktadir $(18,19,29)$.

\subsubsection{Adjuvan ajanlar:}

Primer olarak ağnı tedavisinde yer alan ilaçlar olmasa da bazı durumlarda analjezik etkinliği artırdığı için tercih edilmektedir. Dünya Sağlık Örgütü, adjuvan ajanların analjezik merdivenin her basamağında yer almasını önermektedir. Adjuvan analjezik ilaç sınıfında antidepresan, lokal anestezik, kortikosteroid, antikonvülzan/antiepileptik gibi ilaçlar yer almaktadır. Adjuvan analjezik ilaçlar ağrı ile ilişkili depresyon, inflamasyon/ödem, uykusuzluk, taşikardi, nöropatik ağrı gibi durumları tedavi etmek için kullanılmaktadır $(21,30,31)$.

Lokal anestezik ilaçlar kısa etki süreleri nedeniyle sınırlı kullanıma sahip olsa da ameliyat sırası ve ameliyat sonrası ağrı kontrolünde sık olarak kullanılmaktadır. Kortikosteroid ilaçlar (deksametazon) birçok nedenden dolayı ameliyat yapılacak hastada kullanılmaktadır. Vücuttaki inflamasyon ve ödemi azaltarak ağrı oluşumunu engellemektedir. Ameliyat öncesi multimodal olarak uygulandığında bu ilaç ameliyat sonrası ağrı yoğunluğunu, opioid kullanımını ve anestezi sonrası bakım ünitesinde kalış süresini azaltmaktadır. Kortikosteroid ilaçların olumsuz reaksiyonları genellikle ilacın uzun süreli kullanımı ile ilişkilendirilmektedir. Deksametazon, hiperglisemiye neden olmasından dolayı prediyabet ve diyabetes mellitüs hastalarında dikkatli kullanılmalıdır $(18,19)$.

\subsection{Farmakolojik olmayan (nonfarmakolojik) yöntemler}

Nonfarmakolojik yöntemler multimodal analjezinin bir diğer ayağını oluşturmaktadır. Analjezik ilaç uygulamalarını ve buna bağlı oluşabilecek komplikasyonları önemli derecede azaltmaktadır. Farmakolojik olmayan yöntemleri farmakolojik yöntemlerden daha avantajlı kılan, nispeten kolay uygulanabilir olması, maliyetinin ucuz olması, genellikle uzman yardımı gerektirmemesidir. Ameliyat sonrası ağrı kontrolünde; eğitim, müzik terapisi, dikkati başka yöne çekme, sıcak/soğuk uygulama, gevşeme, masaj, akupunktur, immobilizasyon ve transkutanöz elektriksel sinir stimülasyonu (TENS) gibi yöntemler nonfarmakolojik uygulamaları içermektedir. Akut ameliyat sonrası ağrı yönetimi için multimodal analjezik klinik uygulama kılavuzlarına göre akupunkturun, masajın veya soğuk uygulamanın diğer ameliyat sonrası ağrı tedavileri ile birlikte kullanımının kanıt düzeyi yetersizdir. Nonfarmakolojik uygulamalarda kanıt düzeyi yüksek yöntemler tercih edilmelidir $(25,32)$.

Cerrahi hemşireler multimodal yaklaşımı (farmakolojik/ nonfarmakolojik) kullanırken bireyler arasındaki biyolojik farklılıkları göz önüne alarak ameliyat sonrası ağrıyı yönetmelidir (11,33). 


\section{Etkili taburculuk:}

Taburculuk eğitimine günübirlik cerrahi öncesi bilgi verilerek başlanmalıdır. Taburculuk planı içerisinde sadece ağrı yönetiminden değil pansuman yapma, yara bakımı, banyo yapma, ameliyat sonrası gelişebilecek komplikasyonlar gibi konulardan bahsedilmelidir (34).

Çoğu hasta taburcu olduktan sonra uzun bir süre yoğun ağrı yaşamaya devam etmektedir. Özşaker ve ark. (2019), yaptığı bir çalışmada günübirlik cerrahi sonrası ağrı yönetimi ile ilgili yapılan taburculuk eğitimlerinin yetersiz olduğunu ortaya koymuştur (12). Ağrı yaşayanların birçoğu yanlış anlaşılmalar, yetersiz bilgilendirme ve ağrının cerrahinin kaçınılmaz bir sonucu olduğu inancı nedeniyle yeterli dozda analjezik ilaç almamaktadır. Özellikle yaşlı, eğitim seviyesi düşük, yalnız yaşayan, sosyoekonomik gücü iyi olmayan hastalar daha uzun süre şiddetli ağrı yaşamaktadır $(8,34)$.

Hastaların analjezik ilaçların ve özellikle de opioidlerin kullanımı ile ilgili kaygıları belirlenmelidir. Bazı hastalar, bağımlılık yapma korkusundan dolayı reçete edilen opioidleri almaktan kaçınır. Opioid analjezik ilaçları doğru dozda ve iyi planlanmış tedavi programı ile kullanıldığında bağımlılık yapacağı yönündeki korkunun yersiz olacağından bahsedilmelidir. Hastaların analjezik ilaçlara uyum gücünü artırmak için hem sözel hem de yazıl1-görsel bilgilendirme yapılmalıdır. Bilgilendirme içerisinde; hangi ilaçların kullanacağı ve bu ilaçların hangi sıklıkla kullanması gerektiği, ne gibi yan etkilerinin olacağı, hangi ilaçlarla etkileşim oluşturabileceği, ilaca bağlı diyetinin değişip değişmeyeceği, herhangi bir sorun yaşadığında arayabileceği kişilerin kim olduğu ve hangi numaraları arayabileceği gibi soruların cevapları yer almalıdır. Hastaya ilaçlarını ağrı yoğunluğu artmadan önce düzenli periyotlarda kullanmanın öneminden bahsedilmelidir. Çünkü ağrıyı önlemek şiddetli ağrıyı kontrol ve tedavi etmekten çok daha kolaydır. Ek olarak, hasta yeterli dozda analjezik ilaç almanın iyileşme ve erken ayağa kalkmadaki önemini kavramalıdır $(4,5,19)$

\section{Taburculuk sonrası izlem:}

Günübirlik cerrahinin bir dezavantajı olan zamanın kısıtlılığı hemşirelerin hasta ile etkileşiminin daha kısa olmasına ve taburculuk eğitiminin yetersiz verilmesine neden olmaktadır. Eve taburcu edildikten sonra hasta ile sürdürülen iletişim sekteye uğramaktadır. Taburculuk sonrası hasta ile daha fazla etkileşimde bulunmak için telefon ile izlem tercih edilmelidir (8). Hemşirelik müdahalesinin ameliyat sonrası ağrının giderilmesindeki etkinliğini değerlendirildiği bir çalışmada telefonla hastaların izlemi yapılmıştır. 5.günde kontrol grubundaki hastaların ortalama ağrı şiddeti 3.55 bulunurken deney grubundaki hastalarda 2.85 bulunmuştur. Yani hemşirelerin telefon görüşmesi yaparak bilgi verdiği hastalarda ağrı daha az yaşanmıştır (9).

Cerrahi hemşireler telefon görüşmeleri sayesinde hastalara unutulmadıkları duygusunu verir. Bu duygu önemlidir çünkü çoğu hasta, evde ağrıyı kontrol altına alamayacağı endişesi nedeniyle eve gitmek istemez (15). Hastalar ameliyattan hemen sonra cerrahi ekip tarafindan verilen bilgiye çok iyi konsantre olamamaktadır. $\mathrm{Bu}$ nedenle hastalar taburculuk sonrası aktarılan bilgiyi hatırlamakta güçlük çekmektedir. Zaman geçtikçe ve konsantrasyonları arttıkça telefonla yapılan görüşmeler çok daha yararlı olmaktadır (9). 
Hasta ve yakınları hastanede olduğu süreç içerisinde gelecekte ağrı ile ilgili yaşayacağı sorunları tahmin edemediği için telefon görüşmesi sayesinde yanıt alabilmektedir. Diğer taraftan hastaların ağrı yönetimi ile ilgili yanlış bilgileri belirlenerek doğru olanları ile değiştirilebilir. Hemşireler ve ameliyat ekibi sık olarak dile getirilen soruları belirleyerek protokoller oluşturabilir. Protokoller, hemşirelerin cerrahi dönemde başka hastaya ve yakınına bilgi vermesinde yararlı olabilir $(8,35)$.

\section{SONUÇ}

Hemşireliğin profesyonel yaklaşımı ve bütüncül bir bakımı için günübirlik cerrahi sonrası ağrı yönetimi ele alınması gereken konulardan biridir. Hastaların ameliyat öncesi eğitimi, ağrı değerlendirmesi, psikolojik rahatlaması ve ağrı tedavisi, ağrı yönetiminin önemli bileşenleridir. Günübirlik cerrahi sonrası ameliyat sonrası ağrı tedavisi; bireye özgü planlanan farmakolojik ve nonfarmakolojik girişimlerin uygulanmasını ve sonuçlarının değerlendirilmesini, preemptif analjezinin uygulanmasını içermektedir. Multimodal ve preemptif analjezik yaklaşımlar daha az yan etki insidansı ile daha etkili analjezi sağlamaktadır. Günübirlik cerrahiden eve taburculuk, hasta ile ilk karşılaşıldığı andan itibaren başlamalıdır. Hastanın kendi ağrı kontrolünü nasıl ele alacağı ve eve taburculukta ağrısını nasıl yöneteceğinden hastaya bahsedilmelidir. Hemşireler, hastaların ameliyat sonrası ağrısıyla ne kadar başa çıktığını öğrenmek için taburculuk sonrası izleme devam etmelidir. Son olarak, hemşirelerin ve hastaların tedavileri yeterli ve uygun şekilde uygulaması günübirlik, cerrahi sonrası ağrı yönetimini önemli ölçüde iyileştirecektir.

\section{Çıkar Çatışması}

Bu çalışmada yazarların çıkar çatışması durumları yoktur.

\section{KAYNAKLAR}

1. Aksoy, G., \& Sayın, Y. Y. (2004). Günübirlik cerrahide hastanın hazırlığı. Cumhuriyet Üniversitesi Hemşirelik Yüksek Okulu Dergisi, 8(2), 39-46.

2. Mitchell, M. J. (2007). Nursing research into modern day surgery: a literature review. Ambulatory Surgery, 13(4), 1-29.

3. Akyolcu, N., Akyüz, N. (2017). Günübirlik cerrahi ve hemşirelik bakımı. G. Aksoy, N. Kanan, N. Akyolcu (Ed.), Cerrahi hemşireliği I genişletilmiş. 2.baskı. (ss.389-404). İstanbul: Nobel Tip Kitabevleri.

4. Yavuz, M. (2017). Günübirlik cerrahi. A. Karadakovan, FE. Aslan (Ed.), Dahili ve cerrahi hastalıklarda bakım 1. cilt. 4. baskı. (ss.309-323). Adana: Nobel Kitabevleri.

5. Royal College of Anaesthetists. Guidelines for the Provision of Anaesthesia Services for Day Surgery 2020. https://www.rcoa.ac.uk/gpas/chapter-6 (Erişim Tarihi: 28 Kasım 2020).

6. Çilingir, D., \& Bayraktar, N. (2006). Günübirlik cerrahi süreci ve hemşirelik bakımı. Hacettepe Üniversitesi Hemşirelik Fakültesi Dergisi, 13(1), 69-81.

7. Taşdemir, N., \& Yavuz, M. (2008). Cerrahi hemşireliğinde aile merkezli yaklaşım. Ege Üniversitesi Hemşirelik Fakültesi Dergisi, 24(1), 91-99.

8. Ead, H. (2016). Addressing the barriers to pain management in ambulatory surgery. Journal of PeriAnesthesia Nursing, 31(1), 83-85. 
9. Dewar, A., Craig, K., Muir, J., Cole, C. (2003). Testing the effectiveness of a nursing intervention in relieving pain following day surgery. Ambulatory Surgery, 10(2), 81-88.

10. Kamming, D., Chung, F., Williams, D., McGrath, B. M., \& Curti, B. (2004). Pain management in ambulatory surgery. Journal of PeriAnesthesia Nursing, 19(3), 174-182.

11. Tharakan, L., Faber, P. (2015). Pain management in day-case surgery. British Journal of Anaesthesia Education, 15(4), 180-183.

12. Özşaker, E., Durak, H., Canbazogulları, Ü. (2019). Günübirlik cerrahide hastaların ameliyat sonrasına ilişkin endişelerinin incelenmesi. Çăgdaş Tip Dergisi, 9(1), 100-105.

13. Shang, A. B., Gan, T. J. (2003). Optimising postoperative pain management in the ambulatory patient. Drugs, 63(9), 855-867.

14. Mitchell, M. (2004). Pain management in day-case surgery. Nursing Standard, 18(25), 33-38.

15. Gupta, A. (2006). Analgesia techniques for day cases. P. Lemos, P. Jarrett, B. Philip (Eds), Day surgery. Development and practice. (ss.209-227). London: International Association for Ambulatory Surgery.

16. Karahan, A., Kav, S., Abbasoğlu, A., Doğan, N. \& Tepe, A. (2010). Günübirlik cerrahiyi takiben hastalar ev ortamındaki deneyim ve güçlükleri. Hemşirelikte Araştırma Geliştirme Dergisi, 12 (3), 38-48.

17. Aydoğdu, Ö., Yılmaz, D., Ü. (2020). Patient's experiences and difficulties at home following day surgery. Turkiye Klinikleri Journal of Nursing Sciences, 12(1), 1-9

18. Allred, K., \& Shaffer, B. (2015). Pain management in the ambulatory surgical patient. Or Nurse Journal, 9(4), 8-11.

19. Moline, B. M. (2001). Pain management in the ambulatory surgical population. Journal of PeriAnesthesia Nursing, 16(6), 388-398.

20. Amata, A. (2010). Pain management in ambulatory/day surgery. A. Kopf, NB. Patel (Eds.), Guide to pain management in low-resource settings. International Association for Study of Pain. (ss.119-121). Washington: IASP.

21. Çavdar, İ., Akyüz, N. (2017). Ameliyat sonrası ağrı ve yönetimi. G. Aksoy, N. Kanan, N. Akyolcu (Ed.), Cerrahi hemşireliği I genişletilmiş. 2.baskı. (ss.367-388). İstanbul: Nobel Tip Kitabevleri.

22. Pasero, C., Ignatavicius, D. D. (2016). Assessment and care of patients with pain. DD. Ignatavicius, M. L. Workman, M. Blair, C. Rebar, C. Winkelman (Eds.). MedicalSurgical Nursing. Eighth edition. (ss.158-226). St. Louis: Elsevier.

23. Erbay, H., Gönüllü, M. (2001). Pediatrik cerrahi hastalarda preemptif analjezi. Turkiye Klinikleri Journal of Medical Sciences, 21(4), 319-323.

24. Manworren, R. C. (2015). Multimodal pain management and the future of a personalized medicine approach to pain. Association of Perioperative Registered Nurses Journal, 101(3), 307-318.

25. Chou, R., Gordon, D.B., De Leon-Casasola, O.A., Rosenberg, J. M., Bickler, S., Brennan, T., et al. (2016). Management of Postoperative Pain: a clinical practice guideline from the American pain society, the American society of regional anesthesia and pain medicine, and the American society of anesthesiologists' committee on regional anesthesia, executive committee, and administrative council. The Journal of Pain, 17(2), 131-157. do1:https://doi.org/10.1016/j.jpain.2015.12.008

26. Yazkan, F. Ö. (2018). Pre-emptif analjezi. Süleyman Demirel Üniversitesi Tıp Fakültesi Dergisi, 25(1), 123-124.

27. Jakobsson, J. G. (2014). Pain management in ambulatory surgery A review. Pharmaceuticals, 7(8), 850-865.

28. Şenyüz, K.Y., Koçaşlı, S. (2017). Cerrahi sonrası ağrıda multimodal analjezi ve hemşirelik yaklaşımı. Sağlık Akademisyenleri Dergisi, 4(2), 90-95. 
29. Arslan, D., Tatlı, A. M., Üyetürk, Ü. (2013). Kansere bağlı ağr1 ve tedavisi. Abant Medical Journal, 2(3), 256-60.

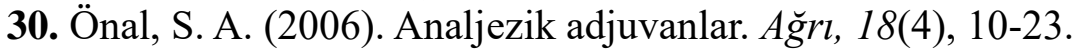

31. Sarıhan, E., Kadığ lu, E., İğde, F. A. (2012). Kanser ağrısı, tedavi prensipleri ve Dünya Sağlık Örgütü ağrı basamak tedavisi. Nobel Med, 8(1), 5-15.

32. Özveren, H. (2011). Ağr1 kontrolünde farmakolojik olmayan yöntemler. Hacettepe Üniversitesi Hemşirelik Fakültesi Dergisi, 18(1), 83-92.

33. Bölükbaş, N., Birlikbaş, S. (2019). ERAS rehberleri cerrahi sonrası hızlandırılmış iyileşme protokolleri. Ordu Üniversitesi Hemşirelik Çalışmaları Dergisi, 2(3), 194-205.

34. Skilton, M. (2003). Post-operative pain management in day surgery. Nursing Standard (through 2013), 17(38), 39-44.

35. Dewar, A., Scott, J., Muir, J. (2004). Telephone follow-up for day surgery patients: Patient perceptions and nurses' experiences. Journal of PeriAnesthesia Nursing, 19(4), 234-241. 